\title{
Assessing Online Teaching Experience during the Covid-19 Pandemic: With Special Reference to the Lecturers Specialized in Management, Sri Lanka
}

\author{
K. A. K. S. Rathnakara \\ Faculty of Management Studies, Rajarata University of Sri Lanka \\ sakurathnakara@gmail.com, sakunthalar@mgt.rjt.ac.lk
}

\begin{abstract}
The entire world was terrifically affected by the Covid-19 pandemic in 2020/21 at different levels. However, almost all the industries including tourism, manufacturing, apparel, education and banking, and finance were utterly affected by this situation. The education sector can be recognized as one of the key sectors deleteriously affected by the pandemic as it created a lot of complications in all the spheres of educational operations including delivering lectures, holding examinations, and conducting assignments. Most of the countries introduced the working from the home concept which was also applied to the education sector as well. Hence; the main objective of this research was to assess the online teaching experience of the Management faculty lecturers in Sri Lanka. This study further explores the difficulties and benefits of online teaching experienced by the lecturers, the level of satisfaction and acceptance of online teaching for future purposes. The findings suggest that lecturers were provided different levels of technical support from their relevant institutes and used different combinations of tools for online teaching. The study further revealed that the main advantage was flexible hours, while; lack of student engagement; lack of face-to-face interactions, internet connection, and technical problems were the most common difficulties. Furthermore, it was found that lecturers were partially satisfied with online education but showed higher acceptance of online education in the future.
\end{abstract}

Keywords: Online teaching, Satisfaction, Acceptance of online teaching, tools, Difficulties and benefits

\section{Introduction}

The education sector is one of the main sectors adversely affected by the Covid - 19 pandemic. The Covid - 19 pandemic affected school education worldwide and led to the closure of schools which was a great impairment for the entire education system. Governments had to close down the schools as well as universities as a precaution to control the spread of the disease. All the stakeholders of the education system were affected by the consequences of the pandemic. As mentioned by Lucas (2020), numerous economic and social cost was created by this pandemic such as interrupted learning, poor nutrition, confusion and stress for teachers, parents being unprepared for distance and homeschooling, challenges in creating, maintaining and improving distance learning, gaps in childcare, increased 
pressure in schools and school systems that remain open, rise in dropout rates, increased exposure to violence and exploitation, social isolation and challenges in measuring and validating learning. Covid- 19 can be considered as one of the most precarious problems which the world had to face in the recent past. Most of the countries declared it as a pandemic and countrywide lockdown and took necessary measures to maintain social distancing measures to control the spread of the virus. This continuous lockdown had a significant impact on the regular studies of the students as well as their psychological well-being.

The Sri Lankan government decided to close down all the universities on $12^{\text {th }}$ March 2020 and the entire education system had to face several issues during this season (Lucas, 2020). Almost all the stakeholders of the higher education system including students, lecturers, parents, university administration of Sri Lanka were affected by the negative consequences of the island-wide curfew. As a remedial action, the government introduced an online platform education system in order to continue the education. However there are benefits as well as difficulties with this system which are inherent to Sri Lankan context. This study was conducted to study the overall effect of online teaching in lecturers' perspective.

\section{Research Problem}

The education sector can be considered as one of the main sectors adversely affected by the Covid -19 pandemic. The Covid - 19 pandemic affected university education worldwide and led to the closure of higher education institutes which was great damage for the entire education system. State universities as well as non-state universities had to shift to an online platform as a remedial action for this challenging situation. However, both lecturers and students had to experience several difficulties in online education platforms. Ample of research studies have been conducted in different countries in order to assess the success and challenges of online education in recent year, especially during the Covid-19 pandemic (Aboagye, Yawson, \& Kofi, 2020; Bakhmat, Babakina, \& Belmaz, 2020; Bao, 2020; Carrillo \& Flores, 2020; Mathew \& Iloanya, 2020; Rameez, Fowsar, \& Lumna, 2020). However, it is worthwhile to conduct a study to assess the online teaching experience of lecturers in the Sri Lankan context as there are very few studies conducted on this area (Rameez, Fowsar, \& Lumna, 2020). Hence; the main focus of this research was on studying the online teaching experience of Sri Lankan university lecturers specialized in Management during the pandemic time. Hence; the problem of the study can be stated as what is the nature of the online teaching experience of the lecturers specialized in Management during Covid -19 pandemic time?

\section{Objectives of the Study}

The main objective of the study is to assess the online teaching experience of the lecturers specialized in Management in Sri Lanka. The subobjectives can be mentioned as follows. 
- $\quad$ To identify the most frequent software used to conduct online lectures in Sri Lanka.

- To identify the level of satisfaction of lecturers specialized in Management on online lectures.

- To explore the issues/ difficulties faced by the lecturers in online teaching.

- $\quad$ To identify the benefits experienced by lecturers in online teaching.

\section{Significance of the Study}

Sri Lankan universities had to shift to online teaching due to the restrictions created by the Covid-19 pandemic as there was no other solution to continue the studies without disruptions. It was a new experience for both lecturers and students so, it is sensible to assess their experience in order to take an overall understanding of the success of the whole process. These findings will be useful for the relevant parties to make decisions in future as it is focused on the difficulties and benefits experienced by the lecturers in online teaching.

\section{Literature Review}

The Sri Lankan university system consists of fifteen state universities and twenty other institutes controlled by the government. According to the Central Bank of Sri Lanka (2020), the overall student intake in 2019 was 129833 students. Furthermore, it mentions that there are 6321 lecturers in state universities and other government higher educational institutes. All the student-related activities such as university admission, assessments, examinations, graduation ceremonies, recruitment, and promotion activities were delayed due to the negative impact of the pandemic. As a remedial action for this situation, the government allowed a work from home strategy, and because of this strategy, universities also introduced online teaching as a remedial action for the interruptions that occurred due to the pandemic situation. This made a total structural change in the traditional education system in Sri Lanka. Different universities and institutes used different platforms to utilize online teaching. There were several difficulties and challenges for the students as well as academic staff as this was a new experience for them. There were several issues related to the cost of internet connection and as a remedial action, the government decided to introduce several measures such as Moodle-based and Zoom application through the Lanka Education and Research Network (LEARN) and some service providers offered free access to universities. However, this facility was not available for non-state universities. As posited by Kee-Ming and Adams (2020), there were several applications available for online learning such as Wikis, discussion boards, blogs, and social media platforms. Conrad (2004) further emphasizes that these applications are facilitating the learners for peer-to-peer learning. Especially most of the lecturers are using WhatsApp groups to update the students regarding lectures and other academic matters. Most of the Sri Lankan universities used Zoom and Microsoft Teams for conducting their online lectures. Examinations and 
other assessments were transformed into online methods. The especially traditional end-of-semester examinations were converted into take-home examinations (Bakhmat, Babakina, \& Belmaz, 2020). On the other hand, some universities introduced online examinations as well. However, the effectiveness of these programs depends on the quality of the infrastructure. From the lecturers' point of view, it has become a challenge to make sure the engagement of the students in online classes.

As mentioned by Mathew and Iloanya (2020), technology is playing a major role in the development and expansion of online education. Furthermore, they mention that usage of technology has enriched our education and created a positive impact on the education process. It was useful to improve the awareness and popularity of online learning among the students as well. Kee-Ming and Adams (2020) mention that there are positive consequences of online teaching as well. Facilitating remote learning approaches and at the same time provides with full experience of using technologysupported learning. Furthermore, it provides a chance for lecturers and students to learn and use the many functions of e-learning systems and applications. In addition to that, the lower usage of papers can be identified as another benefit as all the examinations and assignments are conducted online. Apart from that Mathew and Iloanya (2020) mentioned that students are benefited from online learning as they can learn at their own pace, can promote interaction, promote higher-order thinking skills, and opportunities for real-time student assessments. Furthermore, Anderson and Simpson (2008) mentioned that online learning improves access and interaction, access to a wide variety of resources that are available online, not outdated, can use social media platforms, needy people in rural areas will get opportunities to learn through online learning and provides global learning opportunities.

As mentioned by Kee-Ming and Adams (2020), lecturers had to face several challenges due to the following reasons; they have to learn to use the LMS before conducting online classes in the shortest possible time with little training and preparation, internet strength problems, lecturers had to match the assessments with online teaching, practical and laboratory studies, marking assessments online exposed lecturers computer vision syndrome, anxiety, panic and stress, and infrastructure gaps. Furthermore, Mathew and Iloanya (2020) mention that there are few challenges in online teaching such as access to technology, digital devices, pedagogical skills of online teaching. Aligning with these ideas, Kebritchi, Lipschuetz, and Santiague (2017) mention that learners have some challenges of learner expectations, readiness for learning, social isolation, and participation. In addition to that, Bozkurt and Sharma (2020) have identified several issues with the learning content in content development and instructions, content and multimedia, instructional strategies, and consideration.

Gonzalez (2009) has mentioned that lack of training and support and lack of incentives are another few 
challenges of online teaching. On the other hand, Murphy (2020) mentions that lecturers are also facing several issues such as the transition from faceto-face to online, communication barriers, instructor's lack of interest, teacher pre-preparation programs, and the online medium, time, and teaching styles. In addition to these, Aboagye, Yawson, and Kofi (2020) indicate that accessibility is the most critical challenge faced by the students and they are facing issues with internet connectivity, using compatible smartphones and laptops. On the other hand, students are unwilling to the new approach (Quezada, Talbot, \& Kristina, 2020). Additionally, they are facing social issues such as participating in group work, assisting each other to perform assignments, and looking at the facing gestures of the lecturer (Sia \& Adamu, 2021). Also, from in lecturers' point of view, they are facing difficulties in teaching online and conducting assessments. As mentioned by Rameez, Fowsar, and Lumna (2020), most Sri Lankan students are facing difficulties as they have limited or no access to the internet which is leading to a lack of accessibility to eLearning by students. Furthermore, they mentioned that undergraduates do not have access to internet connections or rather lack network coverage, this had posed a tremendous challenge to continue their online education. The interest of the students will be diminished with the low speed of internet connectivity as it creates interruptions to the ongoing lectures.

\section{Methodology}

According to Central Bank Sri Lanka (2019), the Sri Lankan university system consists of fifteen state universities and twenty governmentcontrolled institutes. 129833 undergraduates are currently studying for their higher education and 6321 lecturers are utilized to cater to the need of these state universities and other institutes. There are twenty-eight non-state universities that are approved by the University Grants Commission (University Grants Commission, 2021). A sample consists of 200 lecturers who are specialized in Management representing both state and non-state sector was randomly selected and 175 participants have responded to the questionnaire. One particular discipline (Management) was selected for the study in order to filter the specific features which are inherent to that particular area of study. Otherwise the researcher will not be able to get an absolute understanding on the particular feild. Research instrument was developed based on the questionnaire developed and used by Bakhmat, Babakina, and Belmaz (2021) and distributed to collect data for the study. A Google form was used for this purpose as it was not possible to physically meet the participants. The questionnaire was distributed among 200 Management faculty lecturers to collect their responses. A simple frequency analysis was conducted in order to analyze data as the researcher has not planned to study a relationship among variables. 


\section{Results}

\section{Demographics of the Respondents}

Table 01: Analyzing Respondents based on Gender

\begin{tabular}{lcc}
\hline & Frequency & Percent \\
\hline Female & 110 & 62.9 \\
Male & 65 & 37.1 \\
Total & 175 & 100.0 \\
\hline
\end{tabular}

Source: Survey Data, 2021

Referring to table 01 , and figure 01 it can be noticed that the majority of the respondents are female $(62.9 \%)$.

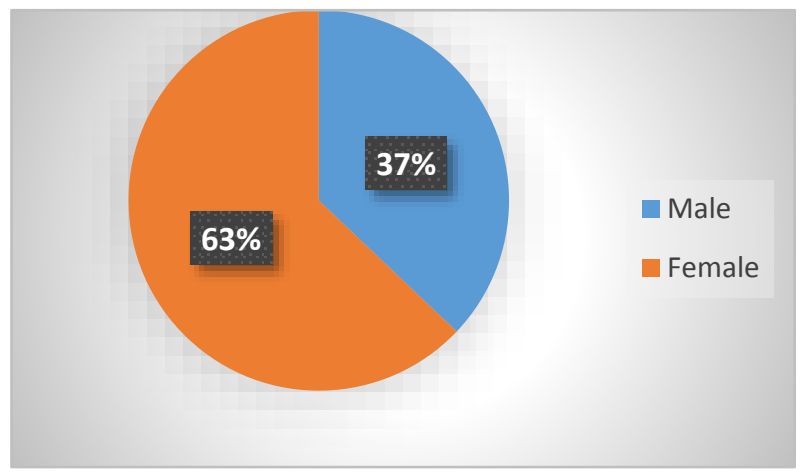

Figure 01: Analyzing Respondents based on Gender

Source: Survey Data, 2021

Table 02 Analyzing Respondents based on the Age Category

\begin{tabular}{lcc}
\hline & Frequency & Percent \\
\hline 20- 30 years & 75 & 42.9 \\
31-40 years & 80 & 45.7 \\
41-50 years & 15 & 8.6 \\
Above 50 years & 5 & 2.9 \\
Total & 175 & 100.0 \\
\hline
\end{tabular}

Source: Survey Data, 2021

Referring to table 02, it can be stated that 45.7 percent of the respondents are in the 31-40 year age category where 42.9 percent of them are in the 21-30 year category. Only 15 percent of the respondents are in 41-50 years and 2.9 percent are in the above 50 years category. Referring to table 03 , it can be stated that 40 percent of the respondents are in the Senior Lecturer 
category where 25.7 percent of them are Lecturer category. 22.9 percent of the respondents are working as temporary lecturers while 11.4 of them are working as probationary lecturers.
Based on the nature of the institute, it can be mentioned that 57.1 percent of the respondents are working for state universities where 43 percent of them are working for non-state universities (see table 04).

Table 03: Analyzing Respondents based on the Designation

\begin{tabular}{lcc}
\hline & Frequency & Percent \\
\hline Lecturer & 45 & 25.7 \\
Lecturer (Probationary) & 20 & 11.4 \\
Lecturer (Temporary) & 40 & 22.9 \\
Senior Lecturer & 70 & 40.0 \\
Total & 175 & 100.0 \\
\hline
\end{tabular}

Source: Survey Data, 2021

Table 04: Analyzing the Respondents based on the Nature of the Institute

\begin{tabular}{lcc}
\hline & Frequency & Percent \\
\hline Non-State University & 75 & 43.0 \\
State University & 100 & 57.1 \\
Total & 175 & 100.0 \\
\hline
\end{tabular}

Source: Survey Data, 2021

Table 05: Analyzing Respondents based on the Training Provided

\begin{tabular}{lcc}
\hline & Frequency & Percent \\
\hline No & 10 & 5.7 \\
Yes & 165 & 94.3 \\
Total & 175 & 100.0 \\
\hline
\end{tabular}

Source: Survey Data, 2021

According to the information provided by the respondents, 94.3 percent of them have been provided training from their relevant institute regarding online teaching where only 5.7 percent of them have mentioned that their institutes have not provided any training (see table 05).

Referring to table 06 , it can be identified that the majority $(42.9 \%)$ of the respondents have used the Zoom platform for conducting their online classes where 25.8 percent have used Microsoft Teams. Only 5.7 percent have used Microsoft Teams and WhatsApp where very few have used combinations of Zoom, LMS, Google, and WhatsApp for delivering their online lectures. 
Rathnakara, KJHRM 2021, 16(01)

Table 06: Analyzing Software for Online Classes

\begin{tabular}{lcc}
\hline & Frequency & Percent \\
\hline Microsoft Teams & 45 & 25.8 \\
Microsoft Teams, WhatsApp & 10 & 5.7 \\
Zoom & 75 & 42.9 \\
Zoom, Google & 5 & 2.9 \\
Zoom, Google, WhatsApp & 5 & 2.9 \\
Zoom, Google, WhatsApp, LMS & 5 & 2.9 \\
Zoom, Microsoft Teams & 15 & 8.6 \\
Zoom, Microsoft Teams, Google, & 5 & 2.9 \\
WhatsApp & 5 & \\
Zoom, Microsoft Teams, WhatsApp & 5 & 2.9 \\
Zoom, WhatsApp & 175 & 2.9 \\
Total & & 100.0 \\
\hline
\end{tabular}

Source: Survey Data, 2021

The majority of the respondents have used LMS for receiving the assignments from the students $(42.9 \%)$ where 31.4 percent of them have used both LMS and email (table 07). Another 14.3 percent have used LMS, email as well as messengers for receiving their assignments.

Table 07: Analyzing Software for Students' Assignments

\begin{tabular}{lcc}
\hline & Frequency & Percent \\
\hline Email & 10 & 5.7 \\
Email, Messengers (Viber, WhatsApp), & 25 & 14.3 \\
Moodle (LMS) & & \\
Email, Moodle (LMS) & 55 & 31.4 \\
Messengers (Viber, WhatsApp) & 5 & 2.9 \\
Moodle (LMS) & 75 & 42.9 \\
Moodle (LMS), Google classroom & 5 & 2.9 \\
Total & 175 & 100.0 \\
\hline
\end{tabular}

Source: Survey Data, 2021

Table 08: Response Level of Satisfaction with Online Education

\begin{tabular}{lcc}
\hline & Frequency & Percent \\
\hline No & 95 & 54.3 \\
Yes & 80 & 45.7 \\
Total & 175 & 100.0 \\
\hline
\end{tabular}

Source: Survey Data, 2021 
As per table 08, it can be stated that 54.3 percent of the respondents are not satisfied with online lectures. Also, referring the table 09 , it can be identified that 65.7 percent of the respondents have a positive opinion regarding conducting online lectures in the future.

Table 09: Respondents' Opinion on Conducting Online Lectures in Future

\begin{tabular}{lcc}
\hline & Frequency & Percent \\
\hline No & 60 & 34.3 \\
Yes & 115 & 65.7 \\
Total & 175 & 100.0 \\
\hline
\end{tabular}

Source: Survey Data, 2021

Referring to table 10 , it can be identified that 86 percent of the respondents are facing an issue with lack of face-to-face interaction where 83 percent of them are experiencing a lack of student engagement in online lectures. 77 percent of them are facing difficulties with internet connection where another 40 percent of them are facing workload and stress as well as motivational issues. Another 43 percent have mentioned there are technical problems as well as issues with the computer competency of the students (37\%). Another 14 percent have mentioned that the universities are not providing adequate support in conducting online lectures.

\section{Table 10: Analyzing the Problems Online Instructors Experienced}

\begin{tabular}{lcc}
\hline & Frequency & Percentage \\
\hline Internet connection issues & 135 & $77 \%$ \\
Technical problems & 75 & $43 \%$ \\
Lack of Student engagement & 145 & $83 \%$ \\
Lack of face-to-face interaction & 150 & $86 \%$ \\
Computer competency of the students & 65 & $37 \%$ \\
Computer competency of yourself & 15 & $9 \%$ \\
Lack of support from universities & 25 & $14 \%$ \\
Workload and stress & 70 & $40 \%$ \\
Motivation issues & 70 & $40 \%$ \\
Working environment & 5 & $3 \%$ \\
\hline
\end{tabular}

Source: Survey Data, 2021

Referring to table 11,91 percent of the respondents have mentioned that they are benefited from flexible hours where another 71 percent have stated that they can efficiently manage their time with online lectures. On the other hand, 57 percent have mentioned that they can effectively use the innovative learning tools where 40 percent have stated they can develop themselves through online lectures. 
Table 11: Analyzing the Benefits Online Instructors Experienced

\begin{tabular}{lcc}
\hline & Frequency & Percentage \\
\hline Time efficiency & 125 & $71 \%$ \\
Flexible hours & 160 & $91 \%$ \\
Self-development & 70 & $40 \%$ \\
Learning tools & 100 & $57 \%$ \\
High Student Reach & 5 & $3 \%$ \\
\hline
\end{tabular}

Source: Survey Data, 2021

\section{Discussion}

Even though eLearning was implemented as a temporary solution for the pandemic situation experienced by the entire world, it has now become new normal for both lecturers and students. However, both lecturers and students had to face a lot of complications as they were not familiar with the online platforms and it was a new experience for them. The main objective of this study was to assess the online teaching experience of university lecturers working for both state and non-state universities with special reference to Management specialization to identify the benefits and issues in their perspective. One particular discipline was selected for the study to specifically identify the issues and concerns which are relevant for that particular discipline. As an example, there may be specific issues related to Information Technology, Science, and Engineering in conducting practical, etc. Hence; the researcher decided to select Management discipline to assess the online teaching experience of the lecturers.

Based on the provided data, it can be noticed that some institutes have not provided special training on online teaching for lecturers. However, it is always important to provide proper training on online teaching as it is a new experience for the lecturers as well. Also, it can be identified that the majority $(42.9 \%)$ of the respondents have used the Zoom platform for conducting their online classes where 25.8 percent have used Microsoft Teams. Only 5.7 percent have used Microsoft Teams and WhatsApp where very few have used combinations of Zoom, LMS, Google, and WhatsApp for delivering their online lectures. The majority of the respondents have used LMS for receiving the assignments from the students $(429 \%)$ where 31.4 of them have used both LMS and email. Another 14.3 percent have used LMS, email as well as messengers for receiving their assignments.

On the other hand, it can be identified that 86 percent of the respondents are facing an issue with lack of face-toface interaction where 83 percent of them are experiencing a lack of student engagement in online lectures. 77 percent of the respondents are facing difficulties with internet connection where another 40 percent of them are facing workload and stress as well as motivational issues. Another 43 percent have mentioned there are technical problems as well as issues with the computer competency of the students (37\%). Another 14 percent 
have mentioned that the universities are not providing adequate support in conducting online lectures. A lot of lecturers are experiencing this internet connection problem as there is no proper coverage in place to provide strong internet connections to the entire country. It can be noticed that most of these issues are in line with the issues found in the previous research studies such as access to technology, digital devices, pedagogical skills of online teaching (Bao, 2020) readiness for learning, social isolation, and participation, the learning content in content development and instructions, content and multimedia, instructional strategies, and consideration, lack of training and support and lack of incentives, the transition from faceto-face to online, communication barriers, instructor's lack of interest, teacher pre-preparation programs, and the online medium, time, and teaching styles (Callo \& Yazon, 2020) internet connectivity, using compatible smartphones and laptops (Aboagye, Yawson, \& Kofi, 2020).

With the difficulties experienced by the lecturers, 91 percent of the respondents have mentioned that they are benefited from flexible hours where another 71 percent have stated that they can efficiently manage their time with online lectures. On the other hand, 57 percent have mentioned that they can effectively use the innovative learning tools where 40 percent have stated they can develop themselves through online lectures. It has been noticed that 54 percent of the respondents are dissatisfied with online teaching, however, 65 of them are happy to implement blended learning in the future.

\section{Conclusion}

As per the findings of this study, it can be concluded that the lecturers who specialized in Management have different opinions on online lectures based on their experience. These findings will be useful for the higher educational institutes to make their future decisions as there are key difficulties as well as few benefits of online lecturing. The responsible authorities can consider these findings in preparation for their plans even after the pandemic situation as there is an option for them to practice blended learning. It will be advisable to conduct further studies focusing on other disciplines as well as there may be specific issues and difficulties as well as benefits based on the nature of the requirements. Especially, Information Technology and Science related studies will reveal a lot of insights as the practical components are essential for them to make the graduates competent in applications. In addition to that, future research studies can be conducted to assess the online learning experience of the undergraduates to assess the same in their perspective. 


\section{References}

Aboagye, E., Yawson, J. A., \& Kofi, N. (2020). COVID-19 and E-Learning: the Challenges of Students in Tertiary Institutions. Social Education Research. DOI: https://doi.org/10.37256/ser.212021422

Anderson, B., \& Simpson, M. (2008). Ethical issues in online education. Open Learning: The Journal of Open, Distance and eLearning, 22(2), 129-138. doi:10.1080/02680510701306673

Bakhmat, , L., Babakina , O., \& Belmaz, Y. (2020). Assessing online education during the COVID-19 pandemic: a survey of lecturers in Ukraine. Journal of Physics: Conference Series. doi:10.1088/1742-6596/1840/1/012050

Bao, W. (2020). COVID-19 and online teaching in higher education: A case study of Peking University. Wiley Periodicals. doi:10.1002/hbe2.191

Bozkurt, A., \& Sharma2, R. C. (2020). Emergency remote teaching in a time of global crisis due to CoronaVirus pandemic. Asian Journal of Distance Education, 15(1).

Callo, E. C., \& Yazon, A. D. (2020). Exploring the Factors Influencing the Readiness of Faculty and Students on Online Teaching and Learning as an Alternative Delivery Model for the New Normal. Universal Journal of Educational Research, 8(8), 3509-3518. doi:10.13189/ujer.2020.080826

Carrillo, C., \& Flores, M. A. (2020). COVID-19 and teacher education: a literature review of online teaching and learning practices. European Journal of Teacher Education, 43(4), 466-487. DOI: 10.1080/02619768.2020.1821184

Central Bank of Sri Lanka. (2020). Economic and Social Statistics of Sri Lanka. Central Bank of Sri Lanka.

Conrad, D. (2004). University Instructors' Reflections on Their First Online Teaching Experiences. Jaln, 8(4).

Gonzalez., C. (2009). Conceptions of, and approaches to, teaching online: a study of lecturers teaching postgraduate distance courses. High Educ, 299-314. doi:10.1007/s10734-008-9145-1

Jones, M. H., \& Gallen, A. (2016). Peer observation, feedback, and reflection for the development of practice in synchronous online teaching. Innovations in Education and Teaching International, 53(6), 616-626. doi:10.1080/14703297.2015.1025808 
Judd, J. B., Rember, B. A., Pellegrini, T., \& Ludlow, B. (n.d.). "This is Not Teaching": The Effects of COVID-19 on Teachers. Action Research for Sustained Change. doi:10.13140/RG.2.2.21599.69285

Kebritchi, M., Lipschuetz, A., \& Santiague, L. (2017). Issues and Challenges for Teaching Successful Online Courses in Higher Education: A Literature Review. journal of Educational Technology Systems, 4-29. DOI: $10.1177 / 0047239516661713$

Lucas, G. N. (2020). COVID-19 pandemic and school education. Sri Lanka Journal of Child Health, 49(3), 207- 209. doi:http://dx.doi.org/10.4038/sljch.v49i3.9135

Mardiana, H. (2020). Lecturers' Attitudes towards Online Teaching in the Learning Process. REGISTER JOURNAL, 77-98. Retrieved from http://journalregister.iainsalatiga.ac.id/index.php/register/

Mathew , I. R., \& Iloanya, J. E. (2020). Open and Distance Learning: Benefits and Challenges of Technology Usage for Online Teaching and Learning in Africa.

Murphy, M. P. (2020). COVID-19 and emergency eLearning: Consequences of the securitization of higher education for post-pandemic pedagogy.

Contemporary Security Policy, 43(1), 492-505.

doi:https://doi.org/10.1080/13523260.2020.1761749

Quezada, R. L., Talbot , C., \& Kristina, B. (2020). From Bricks and Mortar to Remote Teaching: A Teacher Education Program's Response to COVID-19. 472-483. doi:10.1080/02607476.2020.1801330

Sia, J. K., \& Adamu, A. A. (2021). Facing the unknown: pandemic and higher education in Malaysia. Asian Education and Development Studies, 263-275. doi:10.1108/AEDS-05-2020-0114 